\title{
Training and Development Programmes as Predictors of students' Academic Performance in Senior Secondary Schools in Osun State, Nigeria.
}

\author{
Felicia Bosede BAMIRE (Ph.D.)* \\ Department of Educational Management, Obafemi Awolowo University, Ile-Ife, Osun State, Nigeria.
}

*Corresponding Author: Felicia Bosede BAMIRE (Ph.D.), Department of Educational Management Obafemi Awolowo University, Ile-Ife, Osun State, Nigeria.

\begin{abstract}
The study assessed teachers' training and development programmes in senior secondary schools in Osun State, Nigeria. Specifically, it examined the rate at which training programmes are organized in the senior secondary; analysed their effect on teachers' effectiveness in lesson delivery, use of instructional materials, and classroom management; and examined the relationship between the training programmes and students' academic performance in the schools. The study used descriptive survey research design. A multistage sampling technique was used to select 340 respondents (comprising 300 teachers, 30 principals, and 10 human resource management officials of the Osun State Ministry of Education). In the first stage, 10 local government areas (LGAs) were randomly selected out of the 30 LGAs and One Area Office in Osun State. In the second stage, three schools were randomly selected from each of the 10 LGAs to give a total of 30 schools. In each school, 10 teachers and one principal were randomly selected, while 10 human resource management officials were purposively selected from the personnel unit of the Ministry of Education in the State. Two research instruments (interview guide and questionnaire) were used to collect data (on the rate at which training programmes are organised for teachers' development in senior secondary school and their effect on the teachers' effectiveness on lesson delivery, use of instructional materials and classroom management) for the study. Content validity was used to ascertain the validity of the instruments, while the internal consistency was established through testre-test method with a co-efficient of 0.78 and 0.80 , respectively. Data collected were analysed using descriptive statistics (percentages, frequency counts) and inferential statistics (correlation analysis). The results showed that seven main types of teachers' training and development programmes were available to Osun state senior secondary school teachers, these are: conferences, seminars, peer-coaching, retreats, workshops, orientation and sandwich. It was revealed that most of the teachers $(81.7 \%$; 84.3\%; 77.3\%; 85.3\%) agreed that conferences, seminars, workshops and sandwich programmes had been organized for teachers atone time or the other respectively while peer coaching, retreat and orientation were seldom organized as many teachers (73.3\%; 94.3\%; 73.3\%) respectively attested that they were never organized. Furthermore, there was a significant but negative correlation( $r=-567, p=0.05)$ between teachers training and development programmes and their effectiveness in lesson delivery, use of instructional materials, and classroom management. Teacher training and development programmes also had a significant but negative correlation $(r=-447, p=0.05)$ with senior secondary school students' performance in public examinations in Osun State. I $t$ was concluded that for teachers' training and development programmes to achieve the purpose of improving students' academic performance, the Government of Osun state, through its Ministry of Education, should put well-structured modalities in place to ensure that all categories of teachers attend and participate in the programmes.
\end{abstract}

Key Words: Students, Academic Performance, Teachers, Training and Development Programme, Reinforcement Learning, Senior Secondary Schools (SSS).

\section{INTRODUCTION}

Staff training and development is vital to improving personnel skill and productivity in any organization. It enhances the individual's capacity to contribute optimally to the development of the organization (Sarbeng, 2013). In a complex organization such as educational institutions which comprise basically human beings, the amount of staff training and development programmesare expected to have a huge impact on staff effectiveness and productivity. According to Cole (2005), Houger (2006), Al Karim \&Islam (2019), human resources are the most valuable assets of any organization because money, machine and materials are useless without man. The effectiveness and success of an organization therefore depends on the people who work in the organization. It therefore 
implies that for the employees in an organization to perform their duties maximally, they need to acquire the relevant skills and knowledge necessary to cope with the changing demands of the organisation, especially in this age of technological advancement.

Staff training and development is a term often used interchangeably across sectors and describes the formal, ongoing efforts that are being made within organizations to improve the performance and selffulfilment of their employees through a variety of educational methods and programmes. Specifically, the training component is considered to be essential by an organization for the safe and efficient delivery of services. It involves programmes which enable employees to improve performance, as it is designed to reduce organizational risks with compliance to local or national policies, and government guidelines.Trainingis defined as the teaching or learning activities carried on for the purpose of helping members of an organization to acquire and apply the knowledge, skills, abilities and attitudes needed by the organization (Monappa \& Saiyadain, 2008). In schools, the training of teachersalong their professional lines is capable of enhancing their performance and productivity in the school (Al Karim \& Islam (2019)). This is becausetraining is capable of improving teachers' knowledge on subject matter, teaching method, use of instructional materials, and classroom management, among others.Trained teachers are therefore in a better position to educate the students. Staff development, refers to all the policies, practices, and procedures used to develop the knowledge, skills, and competencies of staff to improve the effectiveness and efficiency of the individual and the school (Butler, 1992). It is a programme aimed at providing the individual staff with development opportunities to ensure that they are able to contribute meaningfully to the achievement oforganizational objectives. McNamara (2008) defined development as a broad ongoing multi-faceted set of activities aimed at bringing someone up or an organization to another threshold of performance, often to perform some job or a new role in the future.It involves a more expansive employee's growth plan for future performance rather than immediate career role improvement. It is also important partly as a requirement for the staff to retaintheir jobs as well as in seeking new knowledge for personal advancement. However, both training and development work hand in hand for providing the right skills and knowledge to employees for both organizational benefit and their own progression. It also helps in building a more efficient, motivated and productive workforce. Akintayo (1996), Oguntimehin (2001), and Afshan, Sobia, Kamran \& Nasir (2012), identified the functions of staff training and developmentto include: increasing productivity;improving the quality of work;improving skills, knowledge, understanding and attitude, enhancing the use of tools and machines; reducing waste, accidents, labour turn-over, lateness, absenteeism as well as eliminatingobsolesce in skills, technologies, methods, products, and capital management, among others.

Teachers, in spite of the training received at the teacher training colleges and universities, still need some in-service or on-the-job training through specialized professionalprogrammes. This is because college and university training programmes are not sufficient enough to provide for the extensive range of learning experience required for graduates to become effective school teachers. As it is in all professions, new teachers learn through experience and it takes years to gain skills needed to be effective on the job. The experienced teachers are even confronted with great challenges on their jobs as a result of technology advancement which has brought changes into the educational procedure and students' learning needs. This implies that if teachers do not have proper professional development themselves, their students' academic achievement will be greatly hampered.

In an attempt to address the training needs of teachers, the Osun State Post-Basic Education Career Development has, as one of its goals, the provision oftrained manpower in the applied sciences, technology and commerce at sub-professional grades. It therefore,becomes imperative to engage the teachers in staff development and training programmesas the success of any educational programme depends solidly on the teachers having the relevant skills, knowledge and competencies (Ajani, 2018). Therefore, strategic professional approach to staff development and training of teachers in senior secondary schools in Osun state is highly necessary to attract and retain an effective and efficient staff who possessthe basicskillsand competencesrequired to ensure that the set goals are achieved at the school level.

\section{Statement Of The Problem}

The importance of staff training and development programmes for the advancement of every organizationincluding the school system, cannot be overemphasized. This provides diverse 
opportunities for teachers to enhance their skills and knowledge towards improving students' academic performance in the schools. Such opportunities are provided by the Osun State post-basic education career development programme and various training institutes, with the aim of effectively training teachers to acquire the relevant knowledge and skills required for school development. According to Ajani (2018), however, the individual objectives, methods, and locations for acquiring the training has become questionable. For example, some teacher training colleges, institutes and programmes are located in obscure places, and they organize sub-optimal programmes in unhygienic locations such as under the tree or in dilapidated primary school buildings, mainly for monetary gains. Most of the teachers who are on-the-job, and are expected to strive to acquire needed knowledge, skills, and competencies towards improving their performance in the teaching profession are always hesitant, as all they are interested in is the certification. Teachers are therefore, not effectively trained for the teaching job. This makes it difficult for the teachers to perform maximally on the job when hired because of the lack of basic skills and capabilities needed for effective instructional delivery, and this is capable of negatively affecting students' academic performance. For instance,out of 36,171 students that sat for Senior Secondary School Examination (SSCE) in 2018 in Osun State, only 14,776 (40.85\%) had 5 credits including Mathematics and English Language NBS (2019). This calls to question, the types and frequency of training and development programmes organized for teachers; its effectiveness on the teaching-learning process, and the effect of the programmes on students' academic performance in the schools. Since teacher training and development is crucial for achieving the educational aims and objectives, and inraising the educational standard through proper school management, effective teaching and good instructional supervision (Louise, 2008), it becomes imperative to investigate how teachers career development programmes in Osun State have achieved the set objectives of improving students' academic performance, hence this study.

\section{OBJeCtives Of THE STUdy}

The main objective of the study is to examine the relationships between teacher training and development programmes and students' academic performance in public secondary schools in Osun State, Nigeria.The specific objectives are to:

(i) examine the types of trainingand development programmes organized for secondary school teachers in Osun State, Nigeria;

(ii) examine the rate at whichtraining and development programmes are organized for teachersin Osun State?

(iii) analyse the effect of thetraining and development programmes on teachers' effectiveness in lesson delivery, use of instructional materials, and classroom management; and

(iv)assess the relationship between teachers' training and development and senior secondary school students' academic performance in Osun State, Nigeria.

\subsection{Research Questions}

The following research questions were raised for the study:

(i) What are the types of training and development programmes organized for secondary school teachers in Osun State, Nigeria?

(ii) How often arethe training and development programmes organized for teachers?

(iii) How have the teachertraining and development programmes affected their effectiveness in lesson delivery, use of instructional materials, and class management?

(iv) What is the relationship between teachers' training and development and senior secondary school students' academic performance in Osun State?

\subsection{Research Hypotheses}

Two null hypotheses were tested in this study:

Ho1: There is no significant relationship between teachers' training \& development programme (TTDP) and teachers'performance in lesson delivery, use of instructional materials, and classroom management. 
Training and Development Programmes as a Predictor of Students' Academic Performance in Senior Secondary Schools in Osun State, Nigeria.

Ho2: There is no significant relationship between teachers training \& development programmes and senior secondary school students' academic performance in Osun State.

\section{THEORETICAL FrAMEWORK}

Several theories, such as experiential learning, social learningand reinforcement theories emphasize the importance of training and development in organizations using different approaches. Experiential learning is an engaged learning process whereby students learn by doing and by reflecting on the experience (Dewey,1938), while social learning theory relates to a learning process which proposes that new behaviours can be acquired by observing and imitating others. While reinforcement learning is based on Markov decision processes in which a combination of an action and a particular state of the environment entirely determines the probability of getting a particular amount of reward as well as how the state will change (Seo \& Lee, 2017). Of these theories, this study is supported and underpinned by the reinforcement learning theory. This theory emphasizes the learning behaviour of a person and suggests that the learner will repeat that behaviour which is attached with a positive outcome or result.Skinner (1984), an economist of behaviourist school of thought, proposed the theory of reinforcement and suggested that training and development programmes should be aligned with the organizational objectives and a positive outcome should be expected from such programmes. According to $\mathrm{Hu}$, Niu, Carrasco, Lennox \& Arvin (2020), reinforcement learning is an area of machine learning concerned with how intelligent agents ought to take actions in an environment in order to maximize the notion of cumulative reward. As learning, training and development are often used interchangeably, reinforcement learning is therefore applicable to human resource managementsuch as career development, with a systematic process to enhance an employee's skills, knowledge, and competency, resulting in better performance in a work setting.

However, managers are increasingly struggling with their employee' diminishing loyalty and organizational commitment and engagement. Employees whosolely align their personal goals with their organisations, and do not explore other opportunities for development and growth, face the most negative consequences in times of change. In other words, employees' career-oriented behaviours change as a function of their consequences.Apart from providing insight for the beginning phases of career development, reinforcement theory can also be used to analyse mid-career issues and crises.Many employees experience career plateaus at the mid of their career and they feel stuck at a particular level. In such a dead-end situation, the most common reactions are job dissatisfaction, frustration, unhappiness and lack of motivation (Su, Kuo, Cheung, Hung, Lu \&Cheng, 2017). What these employees are experiencing in terms of reinforcement theory is lack of reinforcing consequences for theirlife's work. They are undergoing an extinction processin which their work behaviours are followed with little or no consequences and unless these consequences for mid-career employees are given prompt attention and are better managed, potentially productive employees with considerable human capital, in termsof experience and tacit knowledge, will become apathetic, indifferent and disengaged. Reinforcement, therefore, provides understanding and support for effective career development that features lateral career movement, job rotation, international assignments, dual-career ladders, work-life balance, and other initiatives that provide mid-career employees with positive consequences that would continue to reinforce their performance.

Furthermore, the concept of reinforcement theory involves several techniques available in human resource management which can be associated with the training and development programmes of staff. These include different types of rewardssuch as bonuses, salary increase, promotion and awarding of certificatewhich can be given after completion of the training and development activities. These rewards will definitely generate positive outcomes for the organization and willgive the trainee(employee)the opportunity to show more interest in the training and development programmes held by the organization. Similarly, the training and development programmes for secondary school teachers should alignwith the set educational goals and objectives, with the utmost expectation that it would impact on the teachers' method of lesson delivery, use of instructional materials and teaching aids, and their classroom management strategies, which should invariablyimpact positively on students'academic performance in the schools.

\subsection{Review of Related Literature}

Training and development are important factors in building the efficiency and effectiveness of both the organization and employees (Raja, Furqan \& Khan, 2011).Employees' training and development 
is a key factor in the economic success of any institution, and educational institution is not an exception (Sarbeng, 2013).Teacher professional development is any type of continuing education effort towards teachers. Teachers play a key role in providing quality education to students. They facilitate learning among students and ensure that they excel academically in order to fulfil their potential. The quality of instruction being passed across to students is now of great concern to stakeholders as it is one of the most critical factors that combine to create overall quality of education (Leu \& Price Rom, 2006).Teacher professional training and development, as a continuing education effort, is therefore imperative as a way by which teachers improve their skill and in turn boost students' academic performance. Studies show that several characteristics are attributed to teachers' quality that impact students' academic performance. Evidence of these findings however, vary based on school level, content areas and students' population. Olaleye (2013) showed that teachers who have a high level of pedagogical training and high level of content knowledge positively affect their students' achievement. Teachers who have undergone training and development programmes are also in a better position to deliver lessons effectively as training improves teachers' knowledge on subject matter, teaching method, and classroom management techniques, among others.Olaleye (2013) also found that teacher development programmes had enhanced and improved their skills in the teaching profession.Morey et al. (2001)stated that training and development programmes such as workshops, seminars and retreats, improve declarative knowledge, planning and task coordination, collaborative problem-solving, and communication skills in task environments. Aragon-Sanchez et al. (2003) found that training activities were positively related to most dimensions of effectiveness and profitability. Oguntimehin (2001) reported that there is a significant and positive relationship between teachers' training and students' test scores. Chiemeka-Unogu (2018) reported that, effectiveness of teachers and school depends on the continuous expansion of their knowledge and skills. He further stated that teacher training and development is the best strategy to strengthen and enhance their performance level and improve the quality of instructional delivery towards enhancing students' achievements, and invariably improving the standard of education. Effective teachers have good strategies for assisting studentslearning byfocusing on learner-centredrather than teacher-centredpedagogy (Bockerts, Pitrich, \& Zeidner, 2000; Asare\& Bediako, 2013). This is reflected in how teachers and students relate together, the learning environment, and the instructional approaches implemented(Hervie \& Winful, 2018). The learning environment should therefore be made interesting and engaging, as students constantly seek for excitement and simply have no tolerance for boredom as a result of their current exposure to technology and digital devices. Thus, when in school, the students have little patience for the lecture method of teaching.It is therefore highly imperative for teachers to reach all learners in the classroom through the use of instructional materialsas it assists teachers in differentiating and facilitating instruction. Teaching aids improve the quality of education in school and also provides the students with the sense of excitement they desire because students read less on their own these days, hence comprehension skill is very low among them. Therefore, teaching aids will help teachers to close the gap by using charts, pictures, concrete objects, magazines, print advertisements and even comic books as viable teaching aids that can assist students to comprehend text (Ahamed, 2015).

Furthermore, teaching aids is a formidable supplement for teachers when the reinforcement of a skill or concept is necessary, especially at the secondary school level when foundation is needed to be laid for the post-secondary education to build upon. Hence,the effectiveness of learning is determined by creating an evaluation strategy, collecting assessment data, and making recommendations for improvement (Roach, 2014).Teachers' professional development is not therefore,effective unless it causes them to improve their instructional delivery strategies.

\section{MeTHOdOLOGY}

The study adopted descriptive survey research design. The population of the study comprised all the seniorsecondary school teachers in the public schools, the Principals and the Human Resource Management (HRM) officials in the Ministry of Education, Osun State, Nigeria. A multi-stage sampling procedure was used to select 340 respondents (comprising 300 senior secondary schoolteachers, 30 Principals, and $10 \mathrm{HRM}$ officials who are in the personnel unit. In the first stage,ten (10) out of the thirty (30) Local Government Areas (LGAs) and one Area office in Osun State, were randomly selected for the study. Ten (10) teachers werethen randomly selected from each school, with their principals, while ten (10) HRM officialsfrom the personnel unit in the Ministry of Education werepurposively selected. 
Two research instruments were used for the study, namely:Interview Guide for the principals, teachers, and HRM officials and questionnaire titled Teachers'Training and Development Programme Questionnaire (TTDPQ).The items of the questionnaires were adapted by the researcher and divided into two sections $\mathrm{A}$ and $\mathrm{B}$, while section $\mathrm{A}$ consisted of demographic information of the teachers, principals and the HRM officials, section B contained 30 items structured in a three-point Likert-type format.

Responses ranged from Never Organised (N), Sometimes Organised (S), and Often Organised (O). The interview guide was also used to elicit responses from 30 teachers, 3 principals and 2 HRM officials randomly selected from the sample used, so as to have their opinion on the types and the rate at whichstaff training and development programmes are being organized in the senior secondary schools and their effect on teachers and students' performance. The two research instruments were validated using face validity and experts' judgement. A test re-test method of reliability was used to determine the reliability of the two instruments. This was done in two schools different from the selected schools. Cronbach's alpha was used to measure the internal consistency of the research instruments. A reliability co-efficient of 0.78 was obtained for TTDPQ and 0.80 for the interview guide which gave consistency estimates of the instruments. Data collected were analysed using descriptive statistics (such as frequency counts and percentages)to examine the types and frequency of teachers' training and development programmes in the schools while inferential statistics(i.e., Pearson Product Moment Correlation analysis)was used to assess the relationship between the training programmes and teachers' effectiveness in lesson delivery, use of instructional materials, and in classroom management, as well as their effect on students' academic performance in the senior secondary schools in Osun state.

\section{RESUlts AND DisCUSSION}

Table1. Background information of respondents (\%)

\begin{tabular}{|c|c|c|c|c|c|}
\hline \multirow[t]{2}{*}{$\mathbf{S} / \mathbf{N}$} & \multirow[t]{2}{*}{ Item } & \multicolumn{4}{|c|}{ Frequency/Percentage $(\%)$} \\
\hline & & $\begin{array}{l}\text { Principal } \\
(n=30)\end{array}$ & $\begin{array}{l}\text { Teacher } \\
(n=300)\end{array}$ & $\begin{array}{l}\text { HRM } \\
\text { Officials } \\
(n=10) \\
\end{array}$ & $\begin{array}{l}\text { All } \\
\text { Respondents } \\
(n=340)\end{array}$ \\
\hline 1. & $\begin{array}{l}\text { Sex of respondents } \\
\text { (i) Male } \\
\text { (ii) Female }\end{array}$ & $\begin{array}{l}10(33.3 \%) \\
20(66.7 \%)\end{array}$ & $\begin{array}{l}102(34 \%) \\
198(66 \%)\end{array}$ & $\begin{array}{l}07(70 \%) \\
03(30 \%)\end{array}$ & $\begin{array}{l}119(35 \%) \\
221(65 \%)\end{array}$ \\
\hline 2. & $\begin{array}{l}\text { Age of respondents } \\
\text { (i) } 20 \text { - } 29 \text { years } \\
\text { (ii) } 30 \text { - } 39 \text { years } \\
\text { (iii) } 40 \text { - } 49 \text { years } \\
\text { (iv) } 50 \text { years and above }\end{array}$ & $\begin{array}{l}- \\
- \\
08(26.7 \%) \\
22(73.3 \%)\end{array}$ & $\begin{array}{l}28(9.3 \%) \\
83(27.7 \%) \\
174(58.0 \%) \\
15(5.0 \%) \\
\end{array}$ & $\begin{array}{l}- \\
02(20 \%) \\
05(50 \%) \\
03(30 \%)\end{array}$ & $\begin{array}{l}28(8.2 \%) \\
85(25.0 \%) \\
187(55.0 \%) \\
40(11.8 \%) \\
\end{array}$ \\
\hline 3. & $\begin{array}{l}\text { Educational Qualification } \\
\text { (i)Grade11/ NCE/HND } \\
\text { (ii) NCE with B(ed), B.A.(ed) } \\
\text { (iii) B.A.(ed), B.(ed), M.(ed) } \\
\text { (iv) } \quad \text { B.A/B.Sc.withor } \\
\text { withoutPGDE/Others }\end{array}$ & $\begin{array}{l}- \\
20(66.7 \%) \\
07(23.3 \%) \\
03(10.0 \%)\end{array}$ & $\begin{array}{l}24(8.0 \%) \\
145(48.3 \%) \\
65(21.7 \%) \\
66(22.0 \%)\end{array}$ & $\begin{array}{l}02(20 \%) \\
05(50 \%) \\
02(20 \%) \\
01(10 \%)\end{array}$ & $\begin{array}{l}26(7.6 \%) \\
170(50.0 \%) \\
74(21.8 \%) \\
70(20.6 \%)\end{array}$ \\
\hline 4. & $\begin{array}{l}\text { Length of Service } \\
\text { (i) } 1-9 \text { years } \\
\text { (ii) } 10-19 \text { years } \\
\text { (iii) } 20-29 \text { years } \\
\text { (iv) } 30 \text { years and above }\end{array}$ & $\begin{array}{l}- \\
- \\
24(80 \%) \\
06(20 \%)\end{array}$ & $\begin{array}{l}44(14.7 \%) \\
111(37.0 \%) \\
119(39.7 \%) \\
26(8.6 \%)\end{array}$ & $\begin{array}{l}02(20 \%) \\
03(30 \%) \\
04(40 \%) \\
01(10 \%)\end{array}$ & $\begin{array}{l}46(13.5 \%) \\
114(33.5 \%) \\
147(43.3 \%) \\
33(9.7 \%) \\
\end{array}$ \\
\hline
\end{tabular}

Source: Fieldwork (2020)

Table 1 shows the summary of the background information of the respondents. Majority $(65 \%)$ of the respondents were females, suggesting that more female teachers than males attended and participated intraining and development programmes. This shows that there is gender disparity in the selection of teachers attending in-service training in the senior secondary schools in Osun state. Teachers' selection for training programmes should be equitable and fair so as to ensure that male teachers are not left behind in the acquisition of new skills. Also, $66.8 \%$ of the respondents were 40 years and above while only $33.2 \%$ were less than 40 years. This shows that most of the respondents attending 
the in-service training were of age, whereas training and development programmes should be focused more on the younger staffwho are still new on the job and who have the potential to work for long period of time. This will afford them the opportunity of improving their job performance. The educational qualification of the respondentsexamined indicated that only $7.6 \%$ of them were holders of Grade11/ NCE/ HND whereas 50\%combined NCEwith B.(ed) and B.A.(ed)while 21.8\% heldtheir Bachelors and Masters in Education without NCE,only (20.6\%) were holders of Bachelors in Arts and Sciences with / without the PGDE. This implies that there is a large number of qualified teachers and principals in the senior secondary schools as well as HRM Officials in the personnel unit in the ministry of education, Osun state. This is supposed to reflect in the level of academic performance of the students. The length of service of the respondents revealed that $86.5 \%$ of them had teaching experience of 10years and above. Thisimplies that the training programmes were being organised for staff who have served for many years instead of organizing it for new staff who still need to be wellguided on the job.

Table2. Teachers' Response on the Rate at which Training and Development Programmes are Organised in Senior Secondary Schools

\begin{tabular}{|l|l|l|l|}
\hline \multicolumn{2}{|l|}{} & Frequency/ Percentages \\
\hline $\begin{array}{l}\text { Teachers' Training and } \\
\text { Developmental Programmes }\end{array}$ & Never Organised (\%) & $\begin{array}{l}\text { Sometimes Organised } \\
(\%)\end{array}$ & Often Organised (\%) \\
\hline Conferences & $47(15.7)$ & $126(42.0)$ & $127(42.3)$ \\
Seminars & $55(18.3)$ & $144(48.0)$ & $101(33.7)$ \\
Peer Coaching & $220(73.3)$ & $60(20.0)$ & $20(6.7)$ \\
Retreats & $283(94.3)$ & $17(5.7)$ & - \\
Workshops & $68(22.7)$ & $140(46.7)$ & $92(30.6)$ \\
Orientation & $219(73.0)$ & $63(21.0)$ & $18(6.0)$ \\
Sandwich & $44(14.7)$ & $65(21.6)$ & $191(63.7)$ \\
\hline
\end{tabular}

Source: Fieldwork (2020)

Table 2 shows the teachers' response on the rate at whichtraining and development programmes are being organisedin Osun state. It was revealed that $84.3 \% ; 81.7 \%$ and $77.3 \%$ of the teachers agreed that conferences, seminars and workshops were organized for teachersrespectively at one time or the other while $73.3 \%, 94.3 \%$ and $73.0 \%$ of the teachers supported that peer-coaching, retreats and orientation programmes were never organized for teachers respectively in the senior secondary schools in Osun state.Out of all the training and development programmes, only peer coaching, retreats and orientation programmes were not adequately organised as $73.3 \%, 94.3 \%$ and $73.0 \%$ respondents claimed never to have attended respectively.This implies that teachers on the job were not adequately assisted in terms of giving them orientation and coaching so as to better understand the requirements of the teaching job. Also, new teachers that are supposedto be given orientation by the experienced ones in order to make the job stress-free are not adequately assisted and also, retreats were notorganized as expected for the old teachers in order to be better briefed and updatedabout the new development and innovation in the teaching job as a result of technological advancement as $21^{\text {st }}$ century teacher.

\subsection{Test of Hypothesis One:}

There is no significant relationship between Teachers Training \& Development Programmes (TTDP) and Teachers'effectiveness in terms of lesson delivery, use of instructional materials, and classroom managementin public senior secondary schools in Osun State.

Table3. Correlation between Training and Development Programmes and Teacher's Effectiveness in the Classroom

\begin{tabular}{|l|l|l|l|l|l|l|}
\hline Variable & Mean & Std. Dev. & N & R & P & Remark \\
\hline $\begin{array}{l}\text { Teacher Training \& Development } \\
\text { Programmes }\end{array}$ & 23.8799 & 4.21890 & 340 & -567 & .000 & Sig. \\
Teachers' Effectiveness & & & & & & \\
\hline
\end{tabular}

** Sig at0.05 level

Table 3shows that there was a significant but negative relationship $(r=-567, p<0.05)$ between TeacherDevelopment Programmes and Teachers' effectiveness in lesson delivery, use of instructional 
materials, and classroom management. This suggests that teacher development programmeshave not enhancedthe teachers' knowledge in terms of lesson delivery, use of instructional materials, and classroom management techniquesas expected. This negates the findings of Chiemeka-Unogu (2018) that the effectiveness of teachers and schools depend on continuous expansion of their knowledge and skills. Olaleye (2013)alsoreported that teachers'development programmes are capable of enhancing and improvingthe skills of those in the teaching profession, if they are well structured and adequately planned. A meaningful development programme in the teaching profession should thereforeentail effective strategic planning and implementation aimed at bringing about positive results from the teachers, who are to put the knowledge and skills acquired to use in their different schools. It is important to note that professional development is not effective unless it has impact on the teachers' lesson delivery, use of instructional materials, and their classroom management techniques which will invariably impact positively on learners' achievement.

\subsection{Test of Hypothesis two:}

There is no significant relationship between Teachers'Training and Development Programmes and Students' Academic Performance in Public Senior Secondary Schools in Osun State.

Table4. Correlation between Teachers Training and Development Programmes and Students' Academic Performance

\begin{tabular}{|l|l|l|l|l|l|l|}
\hline Variable & Mean & Std. Dev. & N & R & P & Remark \\
\hline Students' Academic Performance & 3.28700 & 1.32014 & 340 & -447 & .001 & Sig. \\
Teachers Training\& Development & 5.8750 & 1.76722 & & & & \\
Programmes & & & & & & \\
\hline
\end{tabular}

** Sig. at 0.05 level

Table 4shows that there was a significant but negative relationship $(r=-447, p<0.05)$ between teachers'training anddevelopment programmesand student's academic performance. For instance, out of 36,171 students that sat for Senior Secondary School Examination (SSCE) in 2018 in Osun State, only 14,776 (40.85\%) had 5 credits including Mathematics and English Language (NBS, 2019). Also, the interview conducted revealed that conferences,seminars, peer-coaching, retreats, workshops, orientation and sandwich were the main types of TTDP in Osun state. However, the interview showed that some of the principals and teachers agreed that teachers' development programmes had some positive impact on learner's academic performance. To the HRM officials, however, newly acquired knowledge by teachers from teachers' training and development programmehas really not impacted positively on the teachers' lesson deliverymethods, their use of instructional materials, and classroom management techniques. This is as reflected in students' academic performance in public examinations in Osun State secondary schools.

Theviews of the Human Resource Management officials therefore corroborate the findings from the study that students of Osun State senior secondary schools' performance in public examinations is not encouraging in spite of some teachers training and development programmes that were made available for teachers in the secondary schools in Osun state. There is however, a need for improvement onthe procedure, contents and frequency ofprofessional development programmes for teachers as their pedagogical and educational abilities, through continuous training and re-training, can effectively enhance their classroom performance. However, the training programmes have to be well planned and carefully implemented to ensure that it meets the teachers' learning needs and invariably improve their method of instructional delivery and classroom management.

\section{CONCLuSion}

Based on the findings of the study, it was concluded that teachers' training and development programmes are imperative to enhance students'academic achievement in senior secondary schools in Osun state, Nigeria. However, the modalities for conducting the training should be well structured and also ensure that attention are paid to theother types of TTDP such as peer coaching, retreat and orientation programmes for the old and new teachers to enable them perform their duty effectively in the classroom. 
Training and Development Programmes as a Predictor of Students' Academic Performance in Senior Secondary Schools in Osun State, Nigeria.

\section{RECOMMENDATIONS}

It is recommended that government should intensify more effortsin organising retreats, peer coaching, and staff orientation for both new and old teachers in order to improve their capability in lesson delivery, use of instructional materials, and classroom management.Also, teacher training and development programmes should be organised continuously for teachers from time to time to keep them abreast of new developments in their various areas of specialization.This will invariably impactpositively on the students' academic performance in the senior secondary schools. Nonetheless, newly hired teachers should be focused when planning for training and development programme, while giving equal opportunity to both male and female teachers in the schools.

\section{REFERENCES}

[1] Afshan, S., Sobia, I., Kamran, A. \& Nasir, M. (2012). Impact of training on employee performance: A study of telecommunication sector in Pakistan. Interdisciplinary Journal of Contemporary Research in Business 4, 646-661.

[2] Ahmed, S.A.\& Michele, R. (2015). "Depreciations without Exports? Global Value chains and the Exchange Rate Elasticity of Exports". World Bank Policy Research Working paper WPS7390 Washington DC.

[3] Ajani, O. A. (2018). Needs for in-service Professional Development of Teachers to Improve Students' Academic Performance in Sub-Saharan Africa.Arts andSocial Science Journal 9: 330.

[4] Akintayo, M. O. (1996). “Upgrading the teacher's status through in-service training by distant Learning system" (DLS) Unpublished. A Public Lecturer at the second convocation ceremony of NTI, NCE by DLS.

[5] Al-Karim, R. \&. Islam, M.W. (2011). How Organisational Training affect employee Performance: A case on Bangladesh Private Banking Sector. International Journal of Entrepreneurial Research 2(4):1-6.

[6] Aragon-Sanchez et al. (2003). Effect of Training on business results. International Journal of Human Resource Management, 14(6)(2003), pp.956-980.

[7] Boekaerts, M., Pintrich, P.R., \& Zeidner, M. (Eds) (2000). Handbook of self-regulation. San Diego, CA: Academic press.

[8] Butlers, J.(1992). Teacher Professional development: An Australian case study. Journal of Education for Teaching. 18,221-238.

[9] Chiemeka-Unogu, C. M. (2018). Principals Participation in Staff Development Programmes for Effective Performance in Public Secondary Schools in Rivers State. International Journal of Scientific Research in Education, 11(2), 204-219.

[10] Cole, M. (2005). New Labour, Globalization and social justice, the role of education in Fischman,G., Mc Laren, P., Sunker, H. \& Lankshear, C. (Eds) Critical Theories, Radical Pedagogies andGlobal Conflicts [3 -2] Lanham: Rowman \& Littlefield.

[11] Dewey, J. (1938). Experience and education. New York: Macmilllan.

[12] Hervie, D.M. \&Winful, E.C. (2018). Enhancing teachers` performance through training and development in Ghana Education Service. (A case study of Ebenezer Senior High School) Journal of Human Resource Management. 6(1): 1-8.

[13] Houger, V.P. (2006). Trends of employee performance collaborative effort between managers and employee's performance improvement. Journal Article 45 (5): 26-31.

[14] Hu. J., Niu, .H. Carrasco, J., Lennox, B., \& Arvin,F. (2020). Voronoi-Based Multi-Robot Autonomous Exploration in Unknown Environments via Deep Reinforcement Learning. IEEE Transactions on Vehicular Technology,2020.

[15] Leu, E. \& Price R. A. (2006). Quality of Italics Education and Teacher Learning: A review of the Literature. Washington DC: Equip, and USAID available at: http://www.equip123.net/docs/El-Quality Ed LitRevew.Pdf.

[16] Louise, S. (2008). Teacher effectiveness. Studymode.com

[17] McNamara, O., Brundrett, M., \& Webb, R.(2008). Primary Teacher: initial teacher education, continuing professional development and school leadership development (Primary ReviewResearch Survey 6/3, Cambridge: University of Cambridge Faculty of Education.

[18] Monappa, A. \& Saiyadam, M. A. (2008) Personnel Management, Tata McGrawhill, New Delhi.

[19] Morey, M., Serras, F., Baguna, J., Hafen, E., Corominas, M., (2001). Modulation of the Ras/MAPK Signalling pathway by the redox function of Selen Option in Drosophila melanogaster. Dev.Biol. 238(1):145-156. 
Training and Development Programmes as a Predictor of Students' Academic Performance in Senior Secondary Schools in Osun State, Nigeria.

[20] National Bureau of Statistics (NBS, 2019). WAEC Results Statistics 2016-2018.

[21] Oguntimehin, A. (2001). Teacher Effectiveness: some Italic practical strategies for successful implementation of Universal Basic Education in Nigeria. African Journal of Educational Management, 9 (1): 151-161.

[22] Olaleye, F.O. (2013). Principals Organizational Management and Students`Academic Achievement in secondary schools in Ekiti State, Nigeria. Singaporean Journal of Business Economics and Management Studies, 2(2).

[23] Pintrich, P.R. (2010). The role of good orientation in self-regulated learning. In M. Boekaerts, P.R. Pintrich \& M. Zeidner (Eds), Handbook of self-regulation Academic press: San Diego. pp 451-502.

[24] Rahmah, M.S.B.A \& Al-Zoubi, S.M. (2011). The Effect of a Training Programme in Improving Instructional Competencies for Special Educational Teachers in Jordan. Educational Research, 2(3): 10211030 .

[25] Raja, K. Furqan, K. \& Muhammad,K. (2011). "Impact of Training and Development on Organizational Performance', Global Journal of Management and Business Research, 11 (7). 62-68.

[26] Roach, T., (2014). Student Perceptionstoward Flipped Learning: New method to increase interaction and active learning in economics. International Review of Economics Education. 17, 74-84.

[27] Sarbeng, I.B. (2013). Staff training and development interventions and teaching performance: Application of Structural Equation Modelling. International Journal of Human Resource. 3(4):159.

[28] Skinner, B.F. (1984). The Evolution of Behaviour Italics. Journal of the Experimental Analysis of Behaviour, 41, 217-221.

[29] Seo, H., \& Lee, D., (2017). Reinforcement Learning and Strategic Reasoning during Social DecisionMaking. The Journal of Neuroscience, 21(1):225-231.

[30] Su. T.W., Kuo, J. H. Cheung, Y. H. , Hung, C. Z., Lu, S.H., \& Cheng, J. W. (2017). Effect of Structural Content Career Plateaus on Job Involvement: Do Institutional / Occupational Intention Matter?

\section{AUTHOR's BIOGRAPHY}

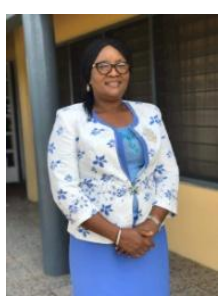

Felicia Bosede Bamire, is a lecturer in the Department of Educational Management, Faculty of Education, Obafemi Awolowo University, Ife, Osun state, Nigeria. She is a member of the Nigeria Association of Educational Administration and Planning (NAEAP) and the Teachers' Registration Council of Nigeria (TRCN), and has attended different conferences, seminars, and workshops largely in her area of specialisation. She has published in both local and international journal outlets in the area of Educational Administration and Supervision. She is married with children.

Citation: Felicia Bosede BAMIRE (Ph.D.). "Training and Development Programmes as Predictors of students' Academic Performance in Senior Secondary Schools in Osun State, Nigeria” International Journal of Humanities Social Sciences and Education (IJHSSE), vol 8, no. 7, 2021, pp. 182-191. doi: https://doi.org/10.20431/2349-0381.0807021.

Copyright: (C) 2021 Authors. This is an open-access article distributed under the terms of the Creative Commons Attribution License, which permits unrestricted use, distribution, and reproduction in any medium, provided the original author and source are credited. 